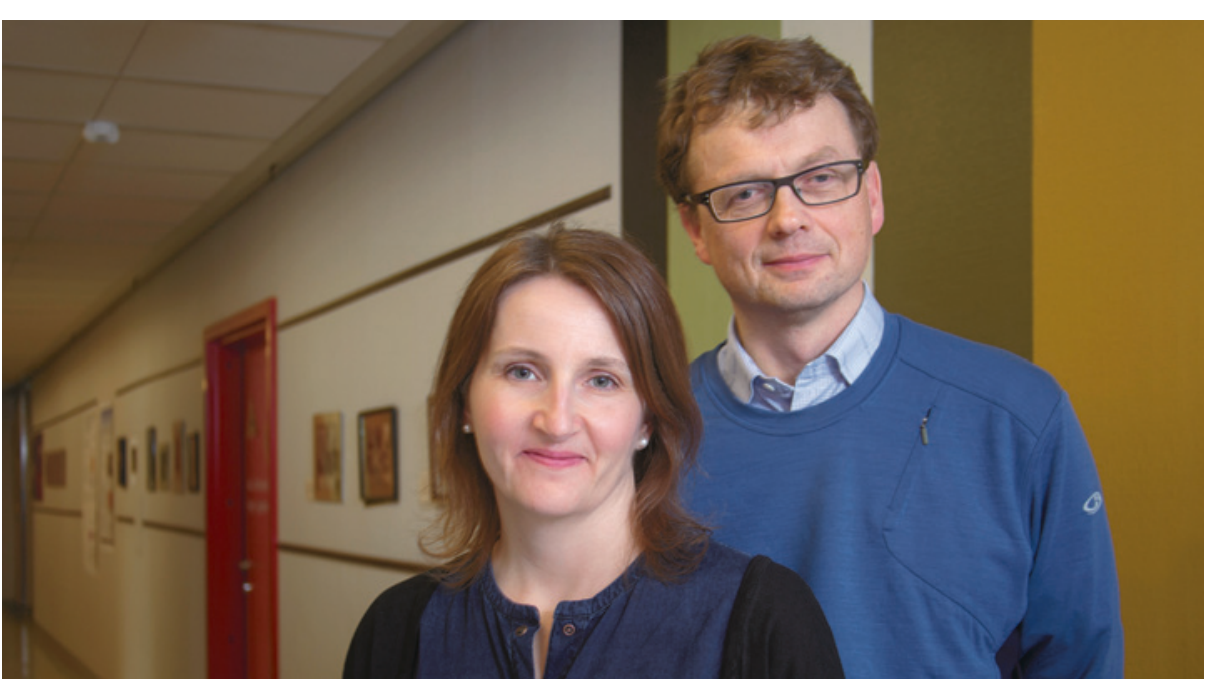

Karianne Fjeld og Anders Molven. Foto: Anne Sidsel Herdlevær, Universitetet i Bergen

\title{
Arvelig risiko for kronisk pankreatitt
}

Forekomsten av hybridgenet CEL-HYB er sterkt økt hos pasienter

med kronisk pankreatitt sammenliknet med normalbefolkningen.

I en norsk studie, publisert i tidsskriftet

Nature Genetics i mars, påvises en ny, arvelig risikofaktor for kronisk pankreatitt (1). Utgangspunktet er en observasjon gjort for mange år siden av Stefan Johansson ved Universitetet i Bergen. Han fant at genet som koder for fordøyelsesenzymet karboksylesterlipase $(C E L)$, hos noen individer har fusjonert med nabogenet $C E L P$ og danner et hybridgen, $C E L-H Y B$. Denne genhybriden gir opphav til et $C E L$-enzym med endret «hale» og med lavere aktivitet enn det normale proteinet.

Mellom 0,7 og $1 \%$ av normalbefolkningen har hybridgenet, mens bærerfrekvensen i de undersøkte pasientene med idiopatisk kronisk pankreatitt lå på 3-4\%. I et begrenset materiale av individer med kjent familiær disposisjon for pankreatitt var frekvensen så høy som $14 \%$. Økt forekomst ble også funnet hos pasienter med alkoholrelatert kronisk pankreatitt. Eksperimenter i cellekulturer viste at sekresjonen av hybridenzymet er hemmet.

- Mekanismen bak danningen av genvarianten er i seg selv uvanlig, men dette er også første gang et lipasegen blir direkte knyttet til kronisk pankreatitt, sier Anders Molven, som er professor i molekylærpatologi ved Universitetet i Bergen. - De fleste genene som øker risikoen for denne sykdommen, fører til overaktivitet i systemet av proteaser i det eksokrine pankreasvevet. $\mathrm{Vi}$ antar at de endrede egenskapene til proteinet CEL stresser de eksokrine cellene og på den måten senker terskelen for inflammatoriske prosesser i pankreas, sier han.

- Interessant nok lar $C E L$-hybridgenet seg sannsynligvis ikke påvise ved genom- vid assosiasjonsanalyse eller eksomsekvensering. Funnet er derfor av generell interesse fordi vi demonstrerer at moderne genetiske forskningsteknikker overser noen deler av arvemassen, sier Molven.

\section{Bergensforskere}

Studien utgår fra KG Jebsen Senter for diabetesforskning ved Universitetet i Bergen (2) og fra flere avdelinger ved Haukeland universitetssykehus, og har vært ledet av Anders Molven. Ved siden av førsteforfatter Karianne Fjeld har professorene Stefan Johansson og Pål R. Njølstad vært sentrale medarbeidere. Utenlandske grupper fra Tyskland og Frankrike har bidratt med store pasientmaterialer - nødvendig for verifisering av sammenhengen mellom $C E L$ og kronisk pankreatitt.

Dette er andre gang disse forskerne publiserer om CEL-genet i Nature Genetics. Allerede i 2006 rapporterte de at punktmutasjoner i $C E L$ fører til en pankreassykdom (CELMODY) karakterisert av eksokrin svikt etterfulgt av diabetes (3).

\section{Lise Mørkved Helsingen}

Tidsskriftet

\section{Litteratur}

1. Fjeld K, Weiss FU, Lasher D et al. A recombined allele of the lipase gene CEL and its pseudogene CELP confers susceptibility to chronic pancreatitis. Nat Genet. 2015; akseptert for publisering.

2. KG Jebsen Senter for Diabetesforskning. http://uib.no/diabetes

3. Ræder H, Johansson S, Holm PI et al. Mutations in the CEL VNTR cause a syndrome of diabetes and pancreatic exocrine dysfunction. Nat Genet 2006; 38: 54-62.

Publisert først på nett.
Ordforklaringer

Hybridgen: En variant av et arveanlegg som har oppstått ved at deler fra to gener er blitt slått sammen til ett gen.

CEL: Genet som koder for fordøyelsesenzymet karboksylesterlipase, et protein som deltar i tarmens absorpsjon av kolesterol og fettløselige vitaminer.

CELP: Nabogenet til CEL. Er regnet som et pseudogen, altså et gen som vanligvis ikke gir opphav til noe funksjonelt protein.

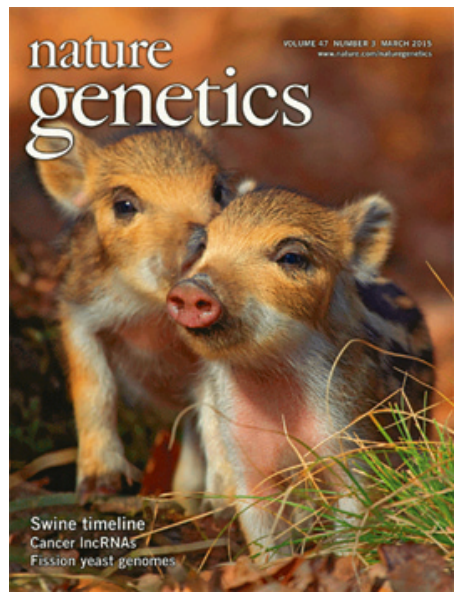

Artikkelen ble e-publisert i Nature Genetics, et av verdens ledende tidsskrift for genetisk forskning, 16.3. 2015 